\title{
Value relevance of accounting information and stock price reaction: Empirical evidence from China
}

\author{
Md. Jahidur Rahman ${ }^{\mathrm{a}, 1}$ and Ruoling Liu $^{\mathrm{a}}$ \\ ${ }^{\mathrm{a}}$ Wenzhou-Kean University
}

\begin{abstract}
Research question: This study investigates whether the release of financial accounting information is related to the change in stock prices.

Motivation: The relationship between accounting information and stock price reaction is well documented in the United States and other major developed economies. However, what is the relationship between share prices and accounting information in emerging economies? According to the standards of Wall Street, London, and Tokyo, the emerging capital markets in the post-communist countries are very small, but they can be a major source of capital for economic growth and development.
\end{abstract}

Idea: For investors, investment decisions about stock should be made by analyzing factors that can influence the stock price. Investors need to have information to determine whether they can benefit from the shares they bought. The financial condition of companies is one of the major information that investors should know.

Data: We obtained data from the A-share market in Shanghai and Shenzhen Stock Exchange of 1,272 listed companies. Data from selected companies' annual report in 20082018 and closing share prices in 2009-2019 were collected. The sample data were from the China Stock Market and Accounting Research database.

Tools: This study used a stepwise regression model to select variables that can provide significant effects and analyzed the regression of added variables and stock price.

Findings: We find that value relevance of accounting number, profitability, liquidity, and

${ }^{1}$ Corresponding authors: Department of Accounting, Wenzhou-Kean University, 88 Daxue Road, Ouhai, Wenzhou, Zhejiang Province, China 325060; Tel: (0577) 55870479; email addresses: mdjahidr@kean.edu 
operational efficiency are positively related to stock price reaction. Other accounting variables, such as earnings per share, current ratio, quick ratio, and debt to equity ratio, have a more significant influence on the market share price. A linear relationship is observed between stock prices and earning per share, current ratio, and quick ratio according to the stepwise regression method.

Contribution: This study provides new insights for academic research and provides additional meaningful and useful information regarding the relevance of companies' accounting information for foreign and domestic investors, specifically domestic investors. This research has scientific and practical usefulness for investors who care about their returns on investments.

Keywords: accounting information, profitability, liquidity, operational efficiency, leverage ability, the stock price

JEL Code: M41, G14

\section{Introduction}

The concept of privatization is a rapidly emerging phenomenon, which refers to the transfer of property rights from the state to enterprises and individuals. Privatization programs are already practiced in emerging countries, such as Africa, Asia, Latin America, and Central and Eastern Europe. Privatization is regarded as a key element in the conversion to a market economy.

The most important objective of privatization is to make market forces and competition inside the economy strong, increase enterprises' performance, and enrich domestic financial markets by building a comprehensive business ownership base (Jermakowicz \& Gornik, 1998). The usual method of collecting capital is debt financing through banks and government agencies. However, raising capital through share offering is an important strategy for developing financial markets to attract investment capital and encourage the efficient use of national resources.

For investors, investment decisions about stock should be made by analyzing the factors that can influence stock price (Chasanah \& Sucipto, 2019). Investors need to have information to determine whether they can benefit from the shares they bought. The financial condition of companies is one of the major information that investors should know (Chasanah \& Sucipto, 2019). The financial statement is a necessary tool for decision-makers to evaluate the overall performance of the company including profitability, liquidity, operational efficiency, and solvency (Ergun, 2012). Ergun (2012) stated that financial statement analysis typically uses financial ratios from different statements. Financial ratios are defined as the numerical value calculated from two or more numbers provided by companies' statements (Arkan, 2016). The financial ratio is a meaningful and useful financial 
information indicator that can be used by various financial information users, specifically investors in the stock market (Wang et al., 2013; Kabajeh et al., 2012). These financial ratios can be classified into four major categories, namely, profitability, liquidity, operation efficiency, and leverage ratios (Kabajeh et al., 2012).

Extensive research investigated the relationship between share price and accounting information and also examined whether the issue of financial accounting information is related to the change in stock prices. The majority of the literature documented the relationship between accounting information and stock price or stock return (Francis \& Schipper, 1999; Lev \& Zarowin, 1999; Chen et al., 2001; Shamki \& Rahman, 2012; Kousenidis et al., 2010; Khanagha, 2011; Takacs, 2012; Ragab \& Omran, 2006; Mishary \& Alanezi, 2011). However, research covering the reaction of stock markets when new and different financial information is release is limited (Ali \& Chowdhury, 2010; Nasar, 2002; Javid \& Faraz, 2011; Dongwei, 2002; Menike \& Wang, 2013).

Value relevance research aims to find whether accounting information published in financial statements provides useful and valuable information for the users of accounting information particularly investors (Negakis, 2005; Mishary \& Alanezi, 2011). Mulenga and Bhatia (2017) extensively and comprehensively reviewed the value relevance of accounting information based on well-emerged or emerging stock markets. They found that earnings per share and book value per share are the most significant and leading variables in value relevance literature. Other accounting variables, such as financial leverage, dividend per share, price-earnings ratio, return on equity, return on assets, and dividend payout ratio, have been used in addition to book value and earnings to determine its significant influence on stock prices. They argued that the different results on value relevance studies from one market to another may be because of accounting regulation differences, the behavior of the market, the methodology used, length of the time period considered, and the number of companies selected as the sample.

The relationship between accounting information and stock price reaction is well documented in the United States and other major developed economies. However, what is the relationship between share prices and accounting information in emerging economies? According to the standards of Wall Street, London, and Tokyo, the emerging capital markets in the post-communist countries are very small, but they can be a major source of capital for economic growth and development. In addition to the economic development role, the emerging markets may provide external investors with a good source of diversification for international portfolio management. The International Finance Corporation, a development institution of the World Bank, has been actively involved in the development of emerging markets (Jermakowicz \& Gornik, 1998).

China's stock market was established in 1990. The Chinese financial market plays an increasingly important role in the emerging economies. The volatility of China's 
equity market has a significant influence on other Asian markets (Hung, 2019). Moreover, stock markets of emerging economies are popular destinations for international investors to obtain benefits of diversification (Hung, 2019). China is one of those popular choices. Based on the importance of the Chinese stock market for the international financial market, the characteristics and operating mechanisms of China's stock market should be understood. The influence of accounting information on listed companies' stock price and investors' behaviors has been discussed for years. Based on the increasing significance of functions and impacts of Chinese-listed companies, this research can provide a further and deep analysis of the relationship between accounting information and stock price in China's stock market for domestic and global investors in emerging economies.

In this study, we hypothesized that the release of financial accounting information is related to the change in stock prices in the Chinese stock market. We obtained data from the A-share market in Shanghai Stock Exchange (SHSE) and Shenzhen Stock Exchange (SZSE) of 1,272 listed companies. Data from selected companies' annual report in 2008-2018 and closing share price in 2009-2019 were collected. Multiple linear regression models and Ohlson's (1995) model were used to analyze the sample data. We find that value relevance of accounting number, profitability, liquidity, and operational efficiency are positively related to stock price reaction. Other accounting variables, such as earnings per share, current ratio, quick ratio, and debt to equity ratio, have a more significant influence on the market share price. A linear relationship is found between stock price and earning per share, current ratio, and quick ratio according to the stepwise regression method.

This study makes a value-added contribution to the existing literature and academic research. First, the results add additional evidence to the existing claim that accounting information is related to the stock price and establishes more comprehensive information. Second, this study is the first to investigate the correlation between accounting information of leverage ability and stock price reaction in China's A-share market. Third, in current theories, researchers prefer to focus on the correlation of earning per share and book value per share to stock price. However, this study identifies debt to equity ratio and liquidity ratios as significant factors that affect the stock price, thereby contributing to existing studies. Therefore, this study provides new insights for academic research and provides additional meaningful and useful information regarding the relevance of companies' accounting information for foreign and domestic investors, specifically domestic investors.

The results also have relevant implications for global portfolio managers to understand how accounting information is relevant to stock price reaction in the Chinese A-share market. These findings might offer them insights in determining investor behaviors of this market and possible influences on other emerging markets. Furthermore, this study proves the correlation between stock price reaction and accounting information, which provides implications for policymakers to enhance corporate governance, transparency, and accountability and make 
financial statements auditing more standardized. Finally, the outcome of the study would be beneficial to the practitioners, academicians, policymakers, and others in emerging economies.

Along with theoretical contribution, this study also contributes in terms of empirical perspective. For example, Wang et al. (2013) investigated the correlation between accounting information and stock price reaction in China. However, our current study is different from Wang et al. (2013) in many ways. For instance, Wang et al. (2013) only focused on 60 listed companies from the SHSE and used sample data of the year 2011 only. However, our study covers over the recent 10year period and includes 1,272 A-share companies from SHSE and SZSE, which has never been studied before in the Chinese stock market. Additionally, the data of this study were from a reliable Chinese database - China Stock Market and Accounting Research (CSMAR). We followed Ohlson's (1995) model and stepwise multiple regression model in the data collection techniques and analytic procedures to select variables that can provide significant effects and analyze the regression of added variables and stock price.

The remaining part of the paper is organized as follows. In Section 2, previous studies and literature are discussed, and hypotheses are developed. In Section 3, the data source and research methodology are introduced. In Section 4, the main results are explained. In Section 5, the study is discussed, and conclusions are provided.

\section{Literature review and hypothesis development}

\subsection{Institutional background of China's stock market}

China's stock market was established in 1990, with a primary goal of privatizing state-owned enterprises, in which the government tightly controlled the selection of firms for listing. Only one-third of shares were tradable in the market until 2005 , and its market capitalization did not reach \$1 trillion until 2006 (Carpenter \& Whitelaw, 2017). In the beginning, China's stock market is different from other stock markets particularly in terms of investor composition and government regulation $(\mathrm{Hu}, 1999)$. In the early time, financial information of listed companies is sometimes not reliable, and the regulatory system for the stock exchange is in the process of developing (Kang et al., 2002). Liu and Liu (2007) agreed that in the early time, accounting information based on Chinese domestic standards might be noisy owing to the sloppy regulation and crony capitalism. In terms of investor composition, most individual investors trade like noise traders who only rely on basic knowledge of investment and sentiment (Kang et al., 2002). Stock prices are driven by market rumors and individual investor's sentiments rather than information because of unavailable and unreliable information and noise traders. Therefore, China's stock market was not valued in the early years because of its small size, scandals, and a bad reputation. 
The reforms and economic development have changed the picture over the decades. China's stock market has grown more than fivefold in market capitalization, and the number of listed companies has more than doubled (Carpenter \& Whitelaw, 2017). Aside from SHSE and SZSE, the two main channels for larger firms, the introduction of small and medium enterprise and ChiNext boards on the SZSE in 2004 and 2009 enables small companies to raise capital (Carpenter \& Whitelaw, 2017). In 2005, the Split-Share Structure Reform unlocked non-tradable shares, and the tradable fraction keeps increasing (Carpenter \& Whitelaw, 2017). China has made several institutional and regulatory improvements. The first attempt is to improve corporate governance, transparency, and accountability at the state and firm levels (Piotroski \& Wong, 2012). To improve the investing environment, the government has implemented regulations requiring convergence toward International Financial Reporting Standards, the application of International Auditing and Assurance Standards, the prohibition on inside traders and the requirement for independent directors, and the practice of anti-corruption programs (Piotroski \& Wong, 2012). The institutions did improve China's investing environment. This research continues to find out whether those regulations increase the value relevance of accounting information, which is defined as the ability of accounting indexes to indicate the information related to the stock prices (Liu \& Liu, 2007).

\subsection{Review of accounting information on stock price reaction}

Accounting information and stock returns have received great attention from academies and practitioners as a measure and control of risk in emerging and developed financial markets. The study on the value relevance is based on capital market-based accounting research and originated from the studies of Beaver (1968) and Ball and Brown (1968). Ball and Brown (1968) investigated the correlation between accounting information and stock price using data from the US stock exchange in New York. They found that investors can obtain an abnormal return from companies having excess earnings which shows the relationship between accounting earnings and stock price. Moreover, Beaver (1968) emphasized from another perspective that the company's financial reporting and accounting information could influence the stock price. Beaver (1968) found that investors used declared accounting information when they trade stock.

Collin et al. (1997) investigated systematic changes in the value relevance of earnings and book values over time. They documented that the value relevance of earnings (book value) decreases (increases) when the firm reports nonrecurring items or negative earnings. Barth, Beaver, and Landsman (1998) investigated the US bankruptcy firms and found that the coefficient on and incremental explanatory power of equity book value increase and those of net income decrease. However, in the case of the emerging capital market, Jermakowicz and Gornik (1998) investigated the association between stock returns and the annual earnings, derived 
from the new accounting and reporting standards, of firms listed on the Warsaw Stock Exchange (WSE) between 1995 and 1997. They found that the annual earnings reported according to new accounting rules by firms listed on the WSE are an important element of the valuation process. Their findings are greatly comparable with the results found in more mature capital markets. This similarity is particularly striking when the results are compared to those for other European countries, such as France, Germany, Belgium, and Italy (Alford et al., 1993). Their findings suggested that despite national and historical differences, environmental influences on accounting in Poland and those countries are quite common, including legal and political systems, culture, and social climate (Adams \& McMillan, 1997).

Cheng and Schaefer (1996) developed a theoretical framework and illustrated how earnings-to-returns relations can be formally modeled in accounting. Later on, using the theory of accounting conservatism, Roychowdhury and Watts (2007) investigated asymmetric timeliness of earnings and the ratio of market value to book value of equity. From the same perspective, Kothari et al. (2010) proposed that generally accepted accounting principles addressed the performance measurement and stewardship challenges that form the nature of financial statements (income statement and balance sheet). They concluded that earnings announcements are value relevant to a firm's valuation.

Ariff and Cheng (2011) and Ariff et al. (2013) found that the stock price of banking firms is significantly affected by the issued earnings information for several countries to determine the relevance of earnings and book value of stock prices. A few years later, Maditinos et al. (2013) found a significant correlation between earnings and returns on the length of the windows of one year and more.

Kwag (2014) investigated the investors' reaction to the earnings announcement and found that investors become more active for the period of earnings reported. In a similar context, Wang (2014) stated that investors assess earnings in accordance with their reactions to earnings news. Moreover, Vijitha and Nimalathasan (2014) found a significant correlation between accounting information, such as earnings per share and return on equity, and stock price. Furthermore, such information is useful and relevant as a key determinant for the stock price. In the meantime, Muller et al. (2015) argued that a relationship exists between equity prices and disclosed fair values of recognized investment property.

Lee (2016) found that managers respond to investors' questions from prepared scripts to avoid any disclosure of bad news during earnings conference calls. AlBaidhani et al. (2017) applied individual stocks and portfolio methods and found a positive (negative) CAR when earnings increase (decrease). They also found that when the portfolio method is used, the size of the earnings response coefficient magnifies showing a stock price response that is very close to the earning size. 


\subsection{Nature of accounting information}

The main purpose of financial statements is to provide accounting information to the investors regarding the company's financial position and performance so that the investors can make better economic decisions (Tharmila \& Nimalathan, 2013; Mulenga \& Bhatia, 2017). Investor's decision whether to invest or not depends on a company's financial performance (Tharmila \& Nimalathan, 2013). The following includes the list of accounting variables used and its definition.

\subsubsection{Profitability}

The profitability of a company can be indicated by profitability ratios. A profitability ratio is an index for companies' overall performance and measures earning capacity, growth, and the success of firms (Kabajeh et al., 2012). These ratios are widely used by investors, and they are necessary to attract investors to purchase companies' shares (Arkan, 2016). Earnings per share, return on shareholder's equity, return on assets, and other profitability ratios indicate accounting information of profitability (Wang et al., 2013; Kabajeh et al., 2012).

\subsubsection{Liquidity}

The liquidity ratio is used to measure how well a firm meets its short-term financial obligations (Watson et al., 2002). If the ratio is high, then the ability to meet the short-term financial duties is strong (Watson et al., 2002). The current, quick, and other ratios are included in the liquidity ratio.

\subsubsection{Operational Efficiency}

Operational efficiency can be measured by operational efficiency ratios. Operational efficiency ratios measure the efficiency with which companies control and manage assets to generate sales and earnings (Arkan, 2016). Based on that, investors can analyze a firm's ability to efficiently utilize resources and convert them into sales and cash (Watson et al., 2002; Arkan, 2016). Greater efficiency can lead to better performance of companies (Watson et al., 2002).

\subsubsection{Leverage}

The firm's risk can be measured by the financial leverage ratio. The financial leverage ratio displays a firm's financial structure and assesses the long-term risk under the structure (Watson et al., 2002), which shows the company's ability to pay the long-term debt (Arkan, 2016). The leverage ratio is also called the gearing or debt ratio. The most common leverage ratios are debt to assets ratio, debt to equity ratio, the long-term debt ratio, and so on. 


\subsection{Hypothesis development}

\subsubsection{Relationship between profitability and stock price reaction}

Earnings per share is a significant factor to explain stock price changes in the US stock market (Ball \& Brown, 1968; Ohlson, 1995; Liu \& Liu, 2007). Dang et al. (2017) stated that earnings per share and return on shareholder's equity have a positive impact on stock price in Vietnam. Arkan (2016) also stated that earnings per share and return on shareholder's equity have an impact on the stock price prediction. In the Chinese stock market, Yu and Huang (2005) and Wang et al. (2013) also found that return on shareholder's equity and earnings per share have a significantly positive correlation to stock price reaction. Based on those previous studies, the accounting information of profitability is positively related to stock price (Collins \& Kothari, 1989; Yu \& Huang, 2005; Liu \& Liu, 2007; Wang et al., 2013). The accounting information of profitability is expected to have a positive correlation with stock price reaction in the Chinese stock market. The following hypothesis is proposed:

H1: The accounting information of profitability is positively related to stock price reaction in China's stock market.

\subsubsection{Relationship between liquidity and stock price reaction}

Heryanto (2016) indicated that liquidity ratios have a positive relationship with a stock price, whereas Chasanah and Sucipto (2019) suggested that liquidity ratios are negatively related to stock price. In the Chinese stock market, Yu and Huang (2005) indicated that the current ratio and quick ratio have a positive correlation with stock price reaction in the SHSE. Wang et al. (2013) also studied listed companies of SHSE and implemented that the accounting information of liquidity has positive effects on the relationship between accounting information and stock price, but the effects are slightly significant. According to previous studies, the hypothesis of liquidity is:

H2: The accounting information of liquidity is positively related to stock price reaction in China's stock market.

\subsubsection{Relationship between operating efficiency and stock price reaction}

Greater efficiency can lead to better performance of companies (Watson et al., 2002). The main ratios in this group are total assets turnover, accounts receivable turnover, inventory turnover, and others. Arkan (2016) found that operational efficiency ratios have no impact on stock price prediction among Kuwaiti companies. In addition, Martani et al. (2009) suggested that total asset turnover is negatively correlated to stock return in the Indonesian market. 
However, among listed companies in the SHSE, the accounting information of operational efficiencies, such as inventory turnover and account receivable turnover, affects stock price reaction positively (Yu \& Huang, 2005). Another research that studied China's stock market has a similar result that efficiency ratio is positively correlated to stock returns, but the influence is slightly significant (Wang et al., 2013). According to that, the following hypothesis of this study is determined:

H3: The accounting information of operational efficiency is positively related to stock price reaction in China's stock market.

\subsubsection{Relationship between leverage and stock price reaction}

Collins and Kothari (1989) found that leverage ratios have inverse effects on the relationship between stock price and accounting information in the American stock market. Gearing ratios are negatively correlated to the stock price in the United State (Easton \& Zmijewski, 1989). However, researchers obtained differing results in Vietnam's stock market using Easton and Harris's (1991) model. Dang et al. (2017) studied Vietnam's stock market and stated that the debt to equity ratio can positively affect the stock price. Tran (2015) drew the same conclusion that leverage ratios have positive impacts on the relationship between accounting information and the stock return.

Based on previous studies, whether leverage ratios have a negative correlation with stock price reaction or not is controversial. However, no evidence can prove the relationship between accounting information of leverage ability and stock price reaction in China. Therefore, the impact of leverage ratios on the relationship between accounting information and stock price reaction using data from China should be studied. Recent research may reflect the relationship between accounting information and stock price more accurately, so the following hypothesis is:

H4: The accounting information of leverage ability is positively related to stock price reaction in China's stock market.

\section{Research methodology}

\subsection{Data source}

Based on the theory of statistics, at least 30 samples can represent the entire population (Wang et al., 2013). The study selected 1,272 A-share listed companies in Shanghai and Shenzhen stock markets as sample data for analysis.

The study used the 2008-2018 annual reports of listed companies as data. The company's annual report usually comes out in late March or April next year, so the price related to financial information is the price after April. Based on that, the 
sample companies' closing price from May 2009 to 2019 was chosen. The sample data were from the CSMAR database.

\subsection{Index selection}

Wang et al. (2013) noted that more than half of investors use eight accounting indexes: (1) Earnings Per Share; (2) Return on Shareholder's Equity; (3) Quick Ratio; (4) Current Ratio; (5) Accounts Receivable Turnover Ratio; (6) Inventory Turnover Ratio; (7) Debt-to-Asset Ratio; (8) Debt-to-Equity Ratio. Earnings per share and return on shareholder's equity represent the accounting information of profitability to measure firms' ability to earn the profit. The current ratio and quick ratio are divided into accounting information of liquidity, showing the ability of firms to meet their short-term liability. Account receivable turnover and inventory turnover are categorized into accounting information of operational efficiency which indicates how efficiently a company manages its assets. Debt to asset ratio and debt to equity ratio represent accounting information of leverage ability to measure companies' ability to fulfill the long-term obligations.

\subsection{Research model}

\subsubsection{Stepwise multiple linear regression model}

This study used a stepwise regression model to select variables that can provide significant effects and analyzed the regression of added variables and stock price. The stepwise multiple linear regression model is a kind of multiple regression models. This model is performed recursively by adding or eliminating an independent predictor at each time to provide the best fit (Liao et al., 2008). After adding a certain number of variables into the regression model in the forward process, the total effects of those variables might interact. Therefore, some predictors that reduce the significance of the current model gradually should be eliminated (Liao et al., 2008). The stepwise multiple linear regression model works by combining the procedures of forwarding selection with backward eliminations.

\subsubsection{Ohlson's (1995) model}

Ohlson's (1995) model provided a basic equation for the regression. Ohlson (1995) created and analyzed a model of the company's fair value as it relates to the current and future earnings, dividends, and book value (Wang \& Chang, 2008). Therefore, Ohlson's (1995) model recognized the stock price as a function of earning per share and the book value of the shares. Wang et al. (2013) implemented Ohlson's (1995) model that a linear relationship exists between accounting information and stock price reaction in China's stock market. According to that, the regression model of stock price and all kinds of financial ratios is as follows: 


$$
\mathrm{P}=\alpha+\beta_{1} \mathrm{EPS}+\beta_{2} \mathrm{ROE}+\beta_{3} \mathrm{QR}+\beta_{4} \mathrm{CR}+\beta_{5} \mathrm{ARR}+\beta_{6} \mathrm{IR}+\beta_{7} \mathrm{DA}+\beta_{8} \mathrm{DE}+\varepsilon,
$$

where P represents stock price, which is the dependent variable for this equation. " $\varepsilon$ " is the influence of accident, " $\alpha$ " stands for the effect of non-accounting information on stock price, and " $\beta$ " is sensitivity. Table 1 shows eight independent variables chosen for study, formulas of these eight financial ratios, and the data source of these variables.

Table 1. Financial ratios

\begin{tabular}{|c|c|c|c|}
\hline Independent & Code & Formula & Category \\
\hline Varia & & & \\
\hline Earnings per share & EPS & $\begin{array}{l}\text { (Net income - Preferred Dividends) / } \\
\text { Weighted Average Shares Outstanding }\end{array}$ & Profitability \\
\hline Return on Equity & ROE & Net income / Total Shareholders' Equity & Profitability \\
\hline Quick ratio & QR & Quick asset / Current liability & Liquidity \\
\hline Current ratio & $\mathrm{CR}$ & Current asset / Current liability & Liquidity \\
\hline Receivable turnover & ARR & Sales / Average Accounts Receivable & Operation \\
\hline Inventory turnover & IR & Cost of Goods Sold / Average Inventory & Operation \\
\hline Debt-to-asset ratio & DA & Total liability / Total asset & Leverage \\
\hline Debt-to-equity ratio & $\mathrm{DE}$ & Total liability / Total Shareholders' Equity & Leverage \\
\hline
\end{tabular}

\section{Results}

\subsection{Descriptive Statistics}

Descriptive statistics can provide basic information about sample data and describe selected data's overall performance (Wang et al., 2013). Table 2 shows the descriptive statistics of accounting information indexes and stock prices from selected companies. The sample comprises 1,272 A-share companies in SHSE and SZSE, with a total number of 13,513 data being processed. The minimum, maximum, and average number and standard deviation of each variable are presented.

Table 2. Descriptive statistics of stock price and accounting information indexes

\begin{tabular}{cccccc}
\hline Indicator & $\mathbf{N}$ & MIN & MAX & AVG & STDEV \\
\hline Stock Price & 13,513 & 1.140 & 315.850 & 12.890 & 11.244 \\
EPS & 13,513 & -5.739 & 8.090 & 0.311 & 0.539 \\
DA & 13,513 & 0.007 & 1.352 & 0.496 & 0.197 \\
DE & 13,513 & 0.003 & 140.245 & 1.710 & 3.099 \\
CR & 13,513 & 0.020 & 204.742 & 1.827 & 2.821 \\
QR & 13,513 & 0.018 & 158.245 & 1.316 & 2.318 \\
ARR & 13,513 & 0.040 & $49,435,345.702$ & $4,433.436$ & $428,175.158$ \\
IR & 13,513 & -0.004 & $14,866.688$ & 18.201 & 253.130 \\
ROE & 13,513 & -163.817 & 1.135 & 0.019 & 1.633 \\
\hline
\end{tabular}




\subsection{Correlation analysis}

Correlation analysis tests the relationship between two or more variables that are linearly related. Table 3 shows the correlations between stock price and EPS, ROE, DA, DE, CR, QR, ARR, and IR. Moreover, the Pearson correlation of earning per share (EPS), return on shareholder's equity (ROE), debt to equity ratio (DE), current ratio (CR), quick ratio $(\mathrm{QR})$, accounts receivable turnover (ARR), and inventory turnover ratio (IR) are positive. However, the Pearson correlation of debt to asset ratio (DA) is negative. Table 3 also presents that the p-values of EPS, DE, $\mathrm{CR}$, and QR are smaller than 0.01 when the correlation is analyzed at the $99 \%$ confidence level. This result indicates a significant relationship between stock price and EPS, DE, CR, and QR.

Table 3. Correlation analysis

\begin{tabular}{|c|c|c|c|c|c|c|c|c|c|}
\hline & & EPS & DA & DE & CR & QR & ARR & IR & ROE \\
\hline \multirow[t]{3}{*}{ SP } & $\begin{array}{l}\text { Pearson } \\
\text { correlation }\end{array}$ & $0.462^{* * *}$ & -0.010 & $0.032^{* *}$ & $0.086^{* *}$ & $0.040^{* * *}$ & 0.016 & 0.013 & 0.009 \\
\hline & Sig. (2-tailed) & 0.000 & 0.263 & 0.000 & 0.000 & 0.000 & 0.057 & 0.128 & 0.301 \\
\hline & $\mathrm{N}$ & 13,513 & 13,513 & 13,513 & 13,513 & 13,513 & 13,513 & 13,513 & 13,513 \\
\hline
\end{tabular}

** Correlation is significant at the 0.01 level (2-tailed).

\subsection{Regression analysis}

For further understanding of the relationship between accounting fundamentals and stock price reaction, the stepwise multiple regression model is used to analyze the sample data. Table 4 indicates the entered variables of multiple regressions. Based on the theory that F-value should not be larger than 0.05, EPS, CR, and QR were selected for regression analysis. Others that are not standard are eliminated.

Table 4. Entered and eliminated variable of regression analysis

\begin{tabular}{ccl}
\hline Model & $\begin{array}{c}\text { Variables } \\
\text { Entered }\end{array}$ & \multicolumn{1}{c}{ Method } \\
\hline 1 & EPS & $\begin{array}{l}\text { Stepwise (Criteria: Probability-of-F-to-enter } \leq 0.050, \\
\text { Probability-of-F-to-remove } \geq 0.100) .\end{array}$ \\
& CR & $\begin{array}{l}\text { Stepwise (Criteria: Probability-of-F-to-enter } \leq 0.050, \\
\text { Probability-of-F-to-remove } \geq 0.100) . \\
\text { Stepwise (Criteria: Probability-of-F-to-enter } \leq 0.050, \\
\text { Probability-of-F-to-remove } \geq 0.100) .\end{array}$ \\
& QR &
\end{tabular}


Table 5 provides a model summary of the regression of accounting information indexes and stock price reaction. This study focused on the adjusted $\mathrm{R}$ square to reduce the effect of independent variables quantities on goodness-of-fit in the equation (Wang et al., 2013). The stepwise regression provided three models. Model 1 only included EPS, and the adjusted R square was 0.213 . Model 2 entered EPS and CR as variables, and the adjusted R square was 0.218 . Model 3 included all three variables (EPS, CR, and QR). The result showed that the adjusted $\mathrm{R}$ square was 0.22 . The adjusted $\mathrm{R}$ square is better if closer to 1 . Therefore, the study focused on Model 3. The adjusted R square was 0.22 , which indicated that $22 \%$ of the total variation in stock price was explained by the regression. The significant Fvalue of model 3 was 0 , which is significant.

Table 5. Results of model summary

\begin{tabular}{|c|c|c|c|c|c|c|c|c|c|}
\hline & \multirow[b]{4}{*}{$\mathbf{R}$} & \multirow{4}{*}{$\begin{array}{c}\mathbf{R} \\
\text { Square }\end{array}$} & \multirow{4}{*}{$\begin{array}{l}\text { Adjusted } \\
\text { R Square }\end{array}$} & \multirow{4}{*}{$\begin{array}{c}\text { Std. } \\
\text { Error }\end{array}$} & \multirow{2}{*}{\multicolumn{4}{|c|}{ Change Statistics }} & \multirow{4}{*}{$\begin{array}{l}\text { Sig. F } \\
\text { Change }\end{array}$} \\
\hline & & & & & & & & & \\
\hline & & & & & \multirow{2}{*}{$\begin{array}{c}\mathbf{R} \\
\text { Square } \\
\text { Change }\end{array}$} & \multirow{2}{*}{$\begin{array}{c}\text { F } \\
\text { Change }\end{array}$} & \multirow[b]{2}{*}{ df1 } & \multirow[b]{2}{*}{ df2 } & \\
\hline Model & & & & & & & & & \\
\hline 1 & $0.462^{\mathrm{a}}$ & 0.213 & 0.213 & 9.97282 & 0.213 & $3,664.938$ & 1 & 13,511 & 0.000 \\
\hline 2 & $0.467^{\mathrm{b}}$ & 0.218 & 0.218 & 9.94430 & 0.005 & 78.610 & 1 & 13,510 & 0.000 \\
\hline 3 & $0.469^{\mathrm{c}}$ & 0.220 & 0.220 & 9.93353 & 0.002 & 30.321 & 1 & 13,509 & 0.000 \\
\hline
\end{tabular}

a. Predictors: (Constant), EPS

b. Predictors: (Constant), EPS, CR

c. Predictors: (Constant), EPS, CR, QR

d. Dependent Variable: SP

Table 6 shows the result of model 3's analysis of variance. The results of ANOVA showed that the significance level of model 3 was 0 at the 95\% confidence level, which is smaller than 0.05 , suggesting that the equation was significant.

Table 6. Results of ANOVA

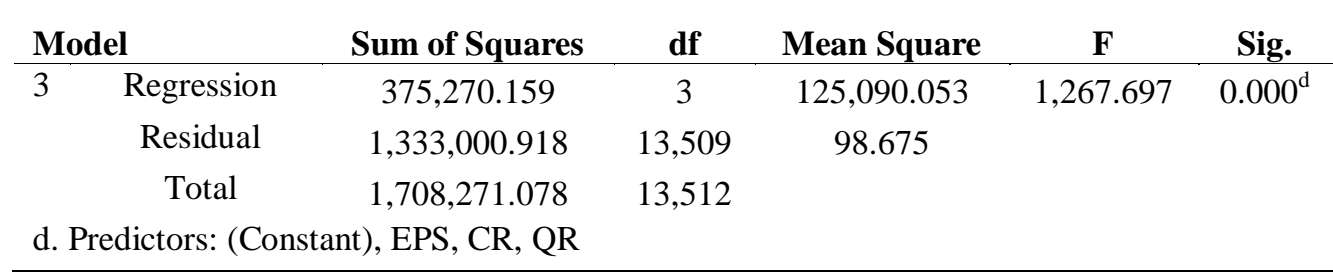

Table 7 displays the coefficients of the equation. B-value indicates the coefficient of each independent variable. The coefficient of EPS was 9.587, the coefficient of CR was 0.268 , and the coefficient of QR was 0.203 . The constant term was 9.150. The confidence level of the constant term, EPS, CR, and QR was all 0, which was smaller than 0.05 at the $95 \%$ confidence level. The VIF value is used for testing multicollinearity. If the VIF values of independent variables in a model are less 
than 10, then multicollinearity has no problem (Dang et al., 2017). Table 7 presents that the VIF of EPS, CR, and QR is less than 10.

Table 7. Coefficients

\begin{tabular}{ccccccccc}
\hline & \multicolumn{2}{c}{$\begin{array}{c}\text { Unstandardized } \\
\text { Coefficients }\end{array}$} & $\begin{array}{c}\text { Standardized } \\
\text { Coefficients }\end{array}$ & \multicolumn{3}{c}{$\begin{array}{c}\text { Collinearity } \\
\text { Statistics }\end{array}$} \\
Model & B & Std. Error & Beta & t & Sig. & Tolerance & VIF \\
\hline 3 (Constant) & 9.150 & 0.122 & & 74.853 & 0.000 & & \\
EPS & 9.587 & 0.159 & 0.459 & 60.399 & 0.000 & 0.998 & 1.002 \\
CR & 0.268 & 0.030 & 0.067 & 8.847 & 0.000 & 0.998 & 1.002 \\
QR & 0.203 & 0.037 & 0.042 & 5.506 & 0.000 & 1.000 & 1.000 \\
\hline
\end{tabular}

\section{Discussion and conclusions}

\subsection{Conclusions}

This study was conducted to examine the correlation between accounting information and stock price in China's A-share stock market. Large sample data of listed A-share companies are from a reliable CSMAR database. A total of 1,272 companies' profitability, liquidity, operational efficiency, and leverage ratios were selected for multiple linear regression and correlation analyses. The results indicated that accounting information on profitability, liquidity, and operational efficiency has a positive impact on stock price reaction, but the significant level varies. Earnings per share, current ratio, and quick ratio are more significant than other indicators. In terms of accounting information of leverage, the debt to equity ratio is significantly positively correlated to the stock price. However, the debt to asset ratio negatively influences stock price reaction. According to the results, when investors enter the stock market, they can rely on those four categories of accounting information, specifically earning per share, current ratio and quick ratio, and debt to equity ratio to make more reliable investment decisions.

Based on this study, future studies can further investigate the relationship between accounting information and stock price reaction in different segments of China's stock market, such as B-shares, H-shares, and AB-shares. A comparison of the impact of accounting information on stock price reactions in different markets can also be studied and discussed. In addition, researchers can study the correlation between accounting information and stock price in different industry backgrounds. Hopefully, future studies will provide insights on these issues.

\subsection{Reliability and validity}

In addition, the study was reliable and valid in several aspects. The data of this study were from a reliable Chinese database - CSMAR. The data collection 
techniques and analytic procedures were based on Ohlson's (1995) model and stepwise multiple regression model. The study also obtained some findings similar to other published journals, and thus, the results are reliable.

In terms of internal validity, the causal relationship between accounting information and stock price reaction has been studied before. Many researchers suggested that a correlation exists between accounting information and stock price (Ball \& Brown, 1968; Collins \& Kothari, 1989; Ohlson, 1995; Yu \& Huang, 2005; Liu \& Liu, 2007; Wang et al., 2013; Dang et al., 2017). Based on results from this study, accounting information is correlated to the stock price in the Chinese stock market. In terms of external validity, the study chose 1,272 companies' available data to do analysis. The sample size was large enough to generalize findings to the Chinese A-share stock market. Therefore, the research is valid.

\subsection{Limitations}

This study has limitations. The study only took companies in China's A-share stock market into consideration. Further studies can discuss the impact of accounting information on stock price reaction in $\mathrm{B}$-share, $\mathrm{H}$-share, and $\mathrm{AB}$-share marketing in China. Other accounting information, such as R\&D expenditure, dividends, and firm size, can also be influential and significance was ignored. Finally, stock prices in different industries may be influenced by different factors. This study only focused on the overall trend of the stock price in the Chinese stock market. Future research can consider the difference in industries.

\subsection{Theoretical contribution}

Whetten (1989) and Corley and Gioia (2011) stated that a complete and valueadded contribution to theory development should take originality and utility into consideration. Thus, the theoretical contribution of this research is attributed to two aspects. For the one aspect, this research has incremental and revelatory insight of previously conducted research. A large portion of studies were conducted to investigate the relationship between accounting information and stock price reaction in developed economies. However, only a small portion of the research was aimed at emerging economies, such as the Chinese capital market. Moreover, this study contributes to existing studies by identifying debt to equity ratio and liquidity ratios as significant factors that affect the stock price. Therefore, this study provides new insights for academic research and provides additional meaningful and useful information regarding the relevance of companies' accounting information for foreign and domestic investors, specifically domestic investors.

For the other aspect, this research has scientific and practical usefulness for 
investors who care about their returns of investments. This research interprets the findings in a readily comprehensible way. The study also suggests that the differing results on value relevance studies from one market to another may be because of accounting regulations differences, the behavior of the market, the methodology used, length of the time period considered, and the number of companies selected as the sample. Hence, this research provides a complete and valuable theoretical contribution to the existing knowledge.

\subsection{Discussion}

Correlation and regression analyses proved that accounting information has an influence on stock price reaction in China's stock market. This result is compatible with the findings from previous studies, indicating that accounting information is related to the stock price in China's stock market (Yu \& Huang, 2005; Wang et al., 2013). However, the significant level varies. Earnings per share (accounting information of profitability), current ratio and quick ratio (accounting information of liquidity), and debt to equity ratio (accounting information of leverage) have significantly positive effects on stock price reaction.

Based on correlation analysis, EPS, ROE, CR, QR, ARR, and IR were positively related to stock price reaction, which indicated that accounting information of profitability, liquidity, and operational efficiency has a positive relationship with stock price reaction. Hypotheses 1, 2, and 3 were supported by this result. Wang et al. (2013) had the same result that in China's stock market, accounting information of profitability, liquidity, and operational efficiency is positively related to stock price reaction. However, accounting information on operational efficiency has a slightly significant relationship with the stock price. The result also indicates that ROE is slightly significant, which is unexpected and different from other findings. Previous studies state that ROE plays an important role in predicting stock price (Yu \& Huang, 2005; Wang et al., 2013; Arkan, 2016; Dang et al., 2017).

Moreover, Table 3 indicates that EPS, DE, CR, and QR have a statistically significant correlation with stock price because the p-value was smaller than 0.01 . This finding is different from another finding. Both findings suggested the importance of EPS, but another finding also proved that ROE is significantly correlated to stock price reaction in China's stock market, and liquidity ratios are slightly significant (Wang et al., 2013), which can be explained. The previous study randomly selected the company from A-share, B-share, and AB-share three markets in China, but this study only focused on the A-shares domestic market. According to the research, the value relevance of accounting information was different among various markets (Liu \& Liu, 2007). In addition, Wang et al. (2013) only considered data from 2011. This study selected data from 2008 to 2018. The sample data were more comprehensive than the previous one. Those reasons might result in differences in results. 
The leverage ratio has not been studied before in China's stock market. This study contributed interesting findings of accounting information on leverage ability. The result proved that the debt to equity ratio has a significant correlation with stock price reaction. Another research had the same conclusion that the debt to equity ratio had a significantly positive influence on stock returns in the Vietnam stock market (Dang et al., 2017). However, the debt to asset ratio had an inverse effect on stock price according to results. Based on the above discussion, Table 8 shows the results of the hypotheses compared with the expected result.

Table 5 shows that $22 \%$ of the variance in stock price is illustrated by the regression as the adjusted $\mathrm{R}$ square is 0.22 . Frost (2019) explained that if the results present a relatively low adjusted $\mathrm{R}$ square, but the independent variables are statistically significant, then the research can still conclude the correlation between variables. In addition, Dontoh et al. (2004) proved a temporary decline in the correlation between accounting information and stock price because of a change from a capital-intensive economy to an innovative and service-based economy.

Table 8. Results of hypothesis

\begin{tabular}{ccc} 
No. & \multicolumn{1}{c}{ Hypotheses } & Results \\
\hline H1 & $\begin{array}{l}\text { The accounting information of profitability is positively related } \\
\text { to stock price reaction in China's stock market. } \\
\text { H2 }\end{array}$ & Accept \\
The accounting information of liquidity is positively related to \\
stock price reaction in China's stock market. \\
The accounting information of operational efficiency is \\
positively related to stock price reaction in China's stock market. \\
The accounting information of leverage ability is positively \\
related to stock price reaction in China's stock market. \\
$\begin{array}{l}\text { Debt to equity ratio is positively related to stock price } \\
\text { reaction in China's stock market. }\end{array}$ & Accept \\
& $\begin{array}{l}\text { Debt to Asset ratio is positively related to stock price } \\
\text { reaction in China's stock market. }\end{array}$ & Reject \\
\hline
\end{tabular}

According to the stepwise multiple regression model, EPS, QR, and CR three variables that can be analyzed in the regression model to offer the best fit. The results of ANOVA suggested that the equation of stock price, earning per share, current ratio, and quick ratio was significant at $p<0.05$. Based on Table 7 , no multicollinearity problem exists because VIF of all variables in model 3 was less than 10. In addition, the function of a multiple regression model was built according to the $\mathrm{B}$ value of all variables in Table 7:

$$
\mathrm{P}=9.15+9.587 \mathrm{EPS}+0.268 \mathrm{CR}+0.203 \mathrm{QR} \text {. }
$$

Investors must consider the accounting information, such as EPS, current ratio, quick ratio, and debt to equity ratio, when making an investment decision. However, public accounting information has not significantly affected the volatility 
of the stock market in China's A-share stock market because the adjusted R square is only $22 \%$. Therefore, investors should take the EPS over share price ratio (PE ratio) into consideration before investing the price.

\section{References}

Adams, C. A., \& McMillan, K. M. (1997) "Internationalizing financial reporting in a newly emerging market economy: The Polish example", Advances in International Accounting, Vol. 10: 139-164

Al-Baidhani, A. M., Abdullah, A., Ariff, M. Cheng, F. F., \& Karbhari, Y. (2017a) "Earnings response coefficient: Applying individual and portfolio methods", Corporate Ownership \& Control, Vol. 14, no. 3: 188-196

Alford, A., Jones, J., Leftwich, R., \& Zmijewski, M. (1993) "The relative informativeness of accounting disclosures in different countries", Journal of Accounting Research, Vol. 31: 183-223

Ali, M. B., \& Chowdhury, T. A. (2010) "Effect of dividend on stock price in emerging stock market: A study on the listed private commercial banks in DSE", International journal of Economics and Finance, Vol. 2, no. 4: 52-64

Ariff, M. \& Cheng, F. F. (2011) "Accounting earnings response coefficient: An extension to banking shares in Asia Pacific countries", Advances in Accounting, Vol. 27, no. 2: 346-354

Ariff, M., Cheng, F.F., \& Soh, W.N. (2013) "Earnings response coefficients of OECD banks: Tests extended to include bank risk factors", Advances in Accounting, Vol. 29, no. 1: 97-107

Arkan, T. (2016) "The importance of financial ratios in predicting stock price trends: A case study in emerging markets", Finanse, Rynki Finansowe, Ubezpieczenia, Vol. 79: 13-26

Ball, R., \& Brown,P.(1968) "An Empirical Evaluation of Accounting Income Numbers", Journal of Accounting Research, Vol. 6, n. 2: 159-178.

Barth, M., Beaver, W., \& Landsman, W. (1998) "Relative valuation roles of equity book value and net income as a function of financial health", Journal of Accounting and Economics, Vol. 25, no. 1:1-34

Beaver, W. (1968) "The information content of annual earnings announcements", Journal of Accounting Research, Vol. 6: 67-92

Carpenter, J. N., \& Whitelaw, R. F. (2017) "The development of China's stock market and stakes for the global economy", Annual Review of Financial Economics, Vol. 9: 233-57

Chasanah, N., \& Sucipto, A. (2019) "Liquidity ratio, profitability, and solvency on stock returns with capital structure as an intervening variable (study on food and beverage sub sector listed in Indonesia Stock Exchange (Idx) period 2013-2017)", Ekspektra: Jurnal Bisnis dan Manajemen, Vol. 3, no. 1: 52-68

Chen, C, Chen, S., \& Su, X. (2001) "Is accounting information value relevant in 
the emerging Chinese stock market?", Journal of International Accounting Auditing \& Taxation, Vol. 10, no. 1: 1-22

Cheng, C. A., Liu, C. S., \& Schaefer, T. F. (1996) "Earnings permanence and the incremental information content of cash flows from operations", Journal of Accounting Research, Vol. 34, no. 1: 173-181.

Collins, D. W., \& Kothari, S. P. (1989) "An analysis of intertemporal and crosssectional determinants of earnings response coefficients", Journal of Accounting and Economics, Vol. 11, n. 2: 143-181

Collins, D., Maydew, E. \&Weiss, I. S. (1997) "Changes in the value relevance of earnings and book values over the past forty years", Journal of Accounting and Economics, Vol. 24, n. 1: 39-67

Corley, K. G., \& Gioia, D. A. (2011) "Building theory about theory building: what constitutes a theoretical contribution?", Academy of Management Review, Vol. 36, no. 1: 12-32

Dang, N. H., Hoang, T. V. H., \& Tran, M. D. (2017) "The relationship between accounting information in the financial statements and the stock returns of listed firms in Vietnam stock exchange", International Journal of Economics and Finance, Vol. 9, n. 10: 1-10

Dongwei, S. (2002) "Stock price reaction to earnings announcement: Evidence from Chinese Market", Review of Financial Economics, North Holland

Dontoh, A., Radhakrishnan, S., \& Ronen, J. (2004) "The declining value-relevance of accounting information and non-information-based trading: an empirical analysis", Contemporary Accounting Research, Vol. 21, no. 4: 795-812

Easton, P. D., \& Harris, T. S. (1991) "Earnings as an explanatory variable for returns", Journal of Accounting Research, Vol. 29, no. 1: 19-36

Easton, P. D., \& Zmijewski, M. E. (1989) "Cross-sectional variation in the stock market response to accounting earnings announcements", Journal of Accounting and Economics, Vol. 11, no. 2-3: 117-141

Ergun, U. (2012) "Internal determinants of the stock price movements on sector basis", International Research Journal of Finance and Economics, Vol. 92: $111-117$

Francis, J., \& Schipper, K. (1999) "Have financial statements lost their relevance?", Journal of Accounting Research, Vol. 37, no. 2: 319-352

Frost, J. (2019) Regression analysis: An intuitive guide for using and interpreting linear models, eBook

Heryanto (2016) "Effect of liquidity and profitability to bank stock return in Indonesia Stock Exchange", International Journal of Academic Research in Accounting, Finance and Management Sciences, Vol. 6, no. 3: 131-138

$\mathrm{Hu}$, J. (1999) "The evolution of China stock market and its institutions", Economic Science, Beijing.

Hung, N. T. (2019) "Return and volatility spillover across equity markets between China and Southeast Asian countries", Journal of Economics, Finance and Administrative Science.

Javid I. \& Faraz, A.F. (2011) "The stock price reaction to earnings announcement: 
The case of an Emerging Market" (Online) Department of Statistics, Karachi University, Pakistan, http://mpra.ub.unimuenchen.de/30865

Jermakowicz, E. K., \& Gornik-Tomaszewski, S. (1998) "Information content of earnings in the emerging capital market: Evidence from the Warsaw Stock Exchange", Multinational Finance Journal, Vol. 2, no. 4: 245-267

Kabajeh, M. A. M., Al Nu'aimat, S. M. A., \& Dahmash, F. N. (2012) "The relationship between the ROA, ROE and ROI ratios with Jordanian insurance public companies market share prices", International Journal of Humanities and Social Science, Vol. 2, no. 11: 115-120

Kang, J., Liu, M. H., \& Ni, S. X. (2002) "Contrarian and momentum strategies in the China stock market: 1993-2000”, Pacific-Basin Finance Journal, Vol. 10, no. 3: 243-265

Khanagha (2011) "Value relevance of accounting Information in the United Arab Emirates", International Journal of Economics and Financial Issues, Vol. 1, no. 2: 33-45

Kothari, S. P., Ramanna, K., \& Skinner, D. J. (2010) "Implications for GAAP from an analysis of positive research in accounting", Journal of Accounting and Economics, Vol. 50, no. 2-3: 246-286

Kousenidis, D.,Ladas, A., \& Negakis, C. (2010) "Value relevance of accounting Information in the pre- and post-IFRS accounting periods", European Research Studies, Vo. 8, no. 1

Kwag, S. W. (2014) "A behavioral shift in earnings response after regulation FD", Journal of Behavioral Finance, Vol. 15, no. 3: 184-194

Lee, J. (2016) "Can investors detect managers' lack of spontaneity? Adherence to predetermined scripts during earnings conference calls", The Accounting Review, Vol. 91, no. 1: 229-250

Lev, B., \& Zarowin, P. (1999) "The boundaries of financial reporting and how to extend them", Journal of Accounting Research, Vol. 37, no. 2: 353-385

Liao, X., Li, Q., Yang, X., Zhang, W., \& Li, W. (2008) "Multiobjective optimization for crash safety design of vehicles using stepwise regression model", Structural and Multidisciplinary Optimization, Vol. 35, no. 6: 561569

Liu, J., \& Liu, C. (2007) "Value relevance of accounting information in different stock market segments: the case of Chinese A-, B-, and H-shares", Journal of International Accounting Research, Vol. 6, no. 2: 55-81

Maditinos, D. I., Šević, Ž., Stankevičienè, J., \& Karakoltsidis, N. (2013) "Earnings response coefficients in the Greek market", Journal of Business Economics and Management, Vol. 14, no. 2: 414-431

Martani, D., Khairurizka, R., \& Khairurizka, R. J. C. B. R. (2009) "The effect of financial ratios, firm size, and cash flow from operating activities in the interim report to the stock return", Chinese Business Review, Vol. 8, no. 6: 44-55

Menike M.G.P.D. \& Wang Man. (2013) "Stock market reactions to the release of annual financial statements: Case of the banking industry in Sri Lanka", 
European Journal of Business and Management, Vol. 5, no. 31:75-87

Mishary, A., \& Alanezi, F. (2011) "Usefulness of earnings and book value for equity valuation to Kuwait stock exchange participants", International Business and Economic Research Journal, Vol. 10, no. 1:73-90

Mulenga, M., \& Bhatia, M. (2017) "The review of literature on the role of earnings, cash flows and accruals in predicting future cash flow", Accounting and Finance Research, Vol. 6, no. 2:59-70

Muller, M. A., Riedl, E. J., \& Sellhorn, T. (2015) "Recognition versus disclosure of fair values", The Accounting Review, Vol. 90, no. 6: 2411-2447

Nasar, K. (2002) "Share price reactions to the release of financial statements in emerging stock Markets: The case of Saudia Arabia", International Financial system and Stock Volatility, Vol. 13, no.1: 87-120

Negakis, J.C. (2005) "Accounting and capital market research. A review", Managerial Finance, Vol. 31, no. 2:1-23

Ohlson, J. A. (1995) "Earnings, book values, and dividends in equity valuation", Contemporary Accounting Research, Vol. 11, no. 2: 661-687

Piotroski, J. D., \& Wong, T. J. (2012) "Institutions and information environment of Chinese listed firms", Capitalizing China, University of Chicago Press, pp. 201-242

Ragab, A., \& Omran (2006) "Accounting information, value relevance, and investors' behavior in the Egyptian equity market", Review of Accounting and Finance, Vol. 5, no. 3: 279-297

Roychowdhury, S., \& Watts, R. L. (2007) "Asymmetric timeliness of earnings, market-to-book and conservatism in financial reporting", Journal of Accounting and Economics, Vol. 44, no. 1-2: 2-31

Shamki, D., \& Rahman, A.A. (2012) "Value relevance of earnings and book value: evidence from Jordan", International Journal of Business and Management, Vol. 7, no. 3:133-141

Takacs (2012) "The value relevance of earnings in a transition economy: Evidence from Romanian stock market", Annales Universitatis Apulensis Series Oeconomica, Vol. 14, no. 1:88-103

Tharmila, K., \& Nimalathasan, B. (2013) "The value relevance of accounting information and its impact on market vulnerability: A study of listed manufacturing companies in Sri Lanka", Research Journal of Finance and Accounting, Vol. 4, no. 18: 030-036

Tran, T. M. H. (2015) "Relationship between accounting information and profitability ratios of listed firms", Doctoral dissertation, Master Thesis, Ho Chi Minh Economics University

Vijitha, P., \& Nimalathasan, B. (2014) "Value relevance of accounting information and share price: A study of listed manufacturing companies in Sri Lanka", Merit Research Journal of Business and Management, Vol. 2, no. 1: 001-006

Wang, H. C., \& Chang, H. J. (2008) "The association between accounting information disclosure and stock price", Global Journal of Business Research, Vol. 2, no. 2: 1-10 
Wang, J., Fu, G., \& Luo, C. (2013) “Accounting information and stock price reaction of listed companies - empirical evidence from 60 listed companies in Shanghai Stock Exchange”, Journal of Business \& Management, Vol. 2, no. 2: 11-21

Wang, Z. (2014) "Measuring investors' assessment of earnings persistence: Do investors see through smoothed earnings?", Review of Quantitative Finance and Accounting, Vol. 42, no. 4: 691-708

Watson, A., Shrives, P., \& Marston, C. (2002) "Voluntary disclosure of accounting ratios in the UK", The British Accounting Review, Vol. 34, no. 4: 289-313

Whetten, D. A. (1989) "What constitutes a theoretical contribution?", Academy of Management Review, Vol. 14, no. 4: 490-495

Yu, H. Y., \& Huang, Y. M. (2005) "A positive analysis on the relationship between stock prices of Shanghai Market and company financial report", Commercial Research, Vol. 4:134-148 